\title{
Post-partum reproductive activity and estrus synchronization responsiveness in anglonubian $x$ sprd fed with dried carnauba wax palm fruit (Copernicia prunifera) long term
}

\section{Atividade reprodutiva e resposta à sincronização de estro no pós- parto em cabras mestiças de anglonubiana $x$ sprd alimentadas com o fruto desidratado da carnaubeira (Copercinia prunifera) por longo tempo}

\author{
Aline Maia Silva ${ }^{1}$; Cláudio Henrique de Almeida Oliveira ${ }^{2}$; \\ César Carneiro Linhares Fernandes ${ }^{3}$; Liliane Moreira Silva ${ }^{4}$; \\ Diana Celia Nunes-Pinheiro ${ }^{5}$; Antonio Amaury Oriá Fernandes ${ }^{5}$; Isadora Machado \\ Teixeira Lima ${ }^{6}$; Cleidson Manoel Gomes da Silva ${ }^{4}$, Davide Rondina ${ }^{5 *}$
}

\begin{abstract}
The present study evaluates the use of dried carnauba wax palm fruit in 28 postpartum goats fed diets containing Bermudagrass hay and either corn (WCWP) or carnauba-based (CWP) concentrated feed. Estrus synchronization was performed 90 days postpartum, and the goats were mated. In the CWP group, compared to the WCWP group, the daily dry matter intake was significantly reduced (646.48 $\pm 11.03 \mathrm{~g}$ vs. $739.29 \pm 3.24 \mathrm{~g}$, respectively; $\mathrm{P}<0.01$ ). The time to the first functional corpus luteum was similar between the groups, occurring a mean 66 days postpartum. During estrus synchronization, the CWP group had a decreased sternal subcutaneous adipose tissue thickness when compared to the WCWP group $(11.93 \pm 0.45 \mathrm{~mm}$ vs. $13.69 \pm 0.57 \mathrm{~mm}$, respectively; $\mathrm{P}<0.05)$ and a lower pregnancy rate $(86.67 \%$ vs. $46.15 \%$, respectively; $\mathrm{P}<0.02)$. The embryonic vesicle and crown-rump length growth rates, and the biparietal, thoracic, and abdominal diameters at 45 days of pregnancy were within normal range for goats in both groups. Litter size at birth was similar between the groups at a mean $1.39 \pm$ 0.11. In conclusion, the substitution of corn with dehydrated carnauba wax palm fruit in concentrated feed for postpartum goats showed no positive effects. Reduced feed intake in the does consuming the carnauba diet caused decreased body reserves, which probably resulted in a decreased pregnancy rate in the affected does.
\end{abstract}

Key words: Carnauba wax palm, goats, pregnancy rate, progesterone

\footnotetext{
1 Discente de Doutorado na RENORBIO, Universidade Estadual do Ceará, UECE, Fortaleza, CE, Brasil. E-mail: nine.maia@, yahoo.com.br

2 Bolsista pós-doutorado, UECE, Fortaleza, CE, Brasil. E-mail: claudiohao@hotmail.com

3 Discente de Doutorado PPGCV, UECE, Fortaleza, CE, Brasil. E-mail: caancesar@gmail.com

4 Profs., Faculdades Integradas do Tapajós, FIT, Santarém, PA, Brasil. E-mail: liligomesvet@hotmail.com; gomesvet@hotmail. com

5 Profs., Universidade Estadual do Ceará, UECE, Fortaleza, CE, Brasil. E-mail: csnpdiana@hotmail.com; amauryoria@hotmail. com; davide.rondina@uece.br

6 Prof ${ }^{\mathrm{a}}$, Faculdade Maurício de Nassau, Fortaleza, CE, Brasil. E-mail: dorinhavet@yahoo.com.br

* Author for correspondence
} 


\section{Resumo}

O presente estudo avaliou o uso do fruto da carnaubeira desidratado em 28 cabras no período pós-parto alimentadas com dieta contendo feno de Tifton e concentrado comercial a base de milho (WCWP) ou com o fruto da carnaubeira (CWP). A sincronização de estro foi realizada aos 90 dias pós-parto e todas as fêmeas foram cobertas. No grupo CWP, em relação ao grupo WCWP, o consumo de matéria seca foi significativamente menor $(646,48 \pm 11,03 \mathrm{~g}$ vs. $739,29 \pm 3,24 \mathrm{~g}$, respectivamente; $\mathrm{P}<0,01)$. O tempo para o aparecimento do primeiro corpo lúteo funcional foi semelhante entre os grupos, ocorrendo em média aos 66 dias pós-parto. No momento da sincronização do estro, o grupo CWP apresentou uma menor espessura do tecido adiposo subcutâneo esternal quando comparado ao grupo WCWP $(13,69 \pm 0,57 \mathrm{~mm}$ vs. 11,93 \pm $0,45 \mathrm{~mm}$, respectivamente; $\mathrm{P}<0,05)$ e uma menor taxa de gestação $(86,67 \%$ vs. $46,15 \%$, respectivamente; $\mathrm{P}<0.02$ ). A taxa de crescimento da vesícula embrionária e do comprimento crânio-caudal, assim como no diâmetro biparietal, torácico e abdominal aos 45 dias de gestação estavam em ambos os grupos dentro do esperado para a espécie em questão. Ao parto a prolificidade não diferiu entre os grupos, com média de $1,39 \pm 0,11$. Em conclusão, a substituição total do milho pelo fruto da carnaubeira no concentrado fornecido às fêmeas caprinas no período pós-parto não apresentou efeitos positivos. A redução da ingestão da dieta nas fêmeas alimentadas com carnaúba levou a uma diminuição das reservas corporais, a qual provavelmente foi a principal causa da diminuição na taxa de gestação nas fêmeas.

Palavras-chave: Cabras, carnaubeira, progesterona, taxa de gestação

\section{Introduction}

The Brazilian semiarid region is characterized by low and irregular rainfall, affecting the livestock food supply during the dry season. Supplemental feeding is employed to minimize the impact on productive and reproductive performance. Alternative food sources such as agro-industrial residues and forest resources that meet the nutritional requirements of livestock and are available in dry periods are an important option in diet planning.

Several agro-industrial by-products have been successfully used in ruminant feed, including sugar cane bagasse (PATE et al., 2002), cupuaçu meal (PEREIRA, 2009), castor bean meal (SILVA et al., 2013), dried cashew bagasse (RODRIGUES et al., 2011) and cassava root scrapings (ARRUDA et al., 2013). In regions experiencing frequent drought, forest resources are an alternative to cattle feed and, according to Araújo Filho et al. (1998), are already included in the diet of goats and sheep in the Caatinga region; 61.9 and $71.4 \%$ of tree and shrub species are consumed by sheep and goats, respectively.

Despite their potential as a low cost and nutritional food source, forest resources have been little explored. Among them, the use of carnauba wax palm has been highlighted; a well-established industry to extract wax from the species already exists. Carnauba wax palm has garnered interest due its numerous potential uses and wide distribution throughout northeastern Brazil. In addition, as a native plant of the region, the species is well adapted to the climate. However, beginning in the 1960 s, its main commercial product, wax, was devalued, and as a result, the carnauba wax palm has become a target for deforestation, and other industries such as irrigated agriculture and shrimp farming. Carnauba wax palm production could reemerge based on investigations aimed at evaluating other potential uses of Copernicia prunifera.

Several studies are of particular interest, namely those assessing chemical constituents and antibacterial properties of the roots (AYRES et al., 2008); those evaluating peroxidase activity within the pericarp (OLIVEIRA et al., 2011); and those characterizing various properties of the fruit, including jelly production (NOGUEIRA et al., 2009), antioxidant capacity and bioactive components (RUFINO et al., 2010), free radical scavenging (RUFINO et al., 2011; SILVA et al., 2005), and suitability for fresh consumption and processing (RUFINO et al., 2009). 
There are contradictory studies reporting the potential use of carnauba wax palm as feed for cattle and goats. Andrade et al. (2008) reported poisoning and death in livestock administered carnauba palm leaf as a sole food source. Gomes et al. (2009, 2010) observed a lower performance on sheep fed diets containing ammoniated carnauba palm leaf residue during the finishing phase. By contrast, carnauba wax supplementation to rodent and canine diets showed no toxic, pathologic, or reproductive effects (ROWLAND et al., 1982; PARENT et al., 1983a, 1983b). No studies have evaluated the use of carnauba wax palm fruit in small ruminant diets.

Goat husbandry in the semiarid region of northeastern Brazil is limited mainly by a restricted food supply, which is determined by scarce and irregular rainfall during the year. Several studies have demonstrated that subnutrition as a consequence of food shortage affects puberty (CHELIKANI et al., 2003), estrous behavior (ZARAZAGA et al., 2005), ovulation, and development of embryos in the pre-implantation stage (VELAZQUEZ, 2015). However, feeding supplementation leads to improved productivity rates by reducing the anestrous interval or acting on the fertility response (MEZA-HERRERA et al., 2004). Thus, the use of alternative foods is a feasible option for the maintenance of livestock, especially if the alternative foods are available during periods of food scarcity.

Carnauba wax palm fruit is abundant during critical periods of drought and are highly sought by animals (ALVES; COELHO, 2006); it could serve as an alternative food to maintain reproductive and productive performance. However, the product must be first validated for use during the relevant reproductive and postpartum periods. Thus, the present study evaluates the effect of carnauba wax palm fruit fed to postpartum goats, particularly on luteal activity recovery, estrus synchronization, fertility, and early fetal development.

\section{Material and Methods}

The study was conducted at the experimental Campo da Semente farm located in the GuaiubaCE municipality at $4^{\circ} 2^{\prime} 23^{\prime \prime} \mathrm{S}$ and $38^{\circ} 38^{\prime} 14^{\prime}$ ' W during 2012 to 2013. A total 28 adult multiparous mixed Anglonubian x Undefined breed (SPRD) pregnant goats were used. At parturition, the subjects were divided into two groups, WCWP and CWP, similar in weight, body score condition, and age $(38.40 \pm 1.83 \mathrm{~kg} ; 2.1 \pm 0.11$; and $26.9 \pm$ 1.32 months, respectively, $\mathrm{p}>0.05)$. The WCWP group $(n=15)$ was fed a diet comprising chopped Bermudagrass hay and a ground corn-based concentrate $(83.75 \%$ corn, $10.7 \%$ soybean meal, and $5.55 \%$ minerals, as fed basis). The CWP group $(n=13)$ received a diet comprising chopped Bermuda grass hay and a concentrate including carnauba wax palm fruit $(79.84 \%$ carnauba fruit, $14.84 \%$ soybean meal, and $5.32 \%$ minerals, as fed basis). All concentrates were isonitrogenous (14.5\% crude protein, dry-matter basis). The ingredient chemical compositions are summarized in Table 1 and the mean diet compositions in Table 2. Both diets satisfied the maintenance and early lactation requirements according to the National Research Council (NRC, 2007) for adult non-dairy does. Both diets contained a 40:60 concentrate:roughage ratio, and both were offered twice daily ( $07 \mathrm{~h} 00$ and 15h00) for 138 days beginning at parturition (Day 0 ) and continuing until 45 days after mating. The experimental animals were kept within group pens, and received mineral salt and water ad libitum. The goats were weighed and the body condition score (BCS) was determined weekly. The kids remained with the does and were weaned at 60 days of age. 
Table 1. Ingredients and composition of diets based on dry matter (DM).

\begin{tabular}{lcc}
\hline \multirow{2}{*}{ Constituents $(\% D M)$} & \multicolumn{2}{c}{ Diet } \\
\cline { 2 - 3 } & WCWP & CWP \\
\hline Ground corn & 83.75 & - \\
Carnauba wax palm fruit & - & 79.84 \\
Soybean meal & 10.70 & 14.84 \\
Urea & 1.00 & 1.00 \\
Vitamin mineralized premix & 4.55 & 4.32 \\
\hline
\end{tabular}

Table 2. Chemical composition of Bermudagrass hay, dried carnauba wax palm fruit and concentrate supplied, based on dry matter (DM).

\begin{tabular}{rrccccc}
\hline \multirow{2}{*}{ Ingredients } & \multicolumn{7}{c}{ Composition (\% DM) } \\
\cline { 2 - 7 } & DM & CP & EE & Ash & NDF & ADF \\
\hline Bermudagrass hay & 88.81 & 10.81 & 2.59 & 7.35 & 72.62 & 35.00 \\
Dried carnauba wax palm fruit & 87.60 & 6.30 & 6.36 & 5.32 & 61.03 & 42.33 \\
Concentrate - based supplements & & & & & & \\
WCWP - diet & 86.26 & 14.52 & 5.19 & 4.09 & 16.37 & 3.36 \\
CWP - diet & 86.93 & 14.50 & 5.35 & 11.62 & 48.37 & 35.05 \\
\hline
\end{tabular}

DM: Dry Matter; CP: Crude Protein; EE: Ether Extract; NDF: Neutral Detergent Fiber; ADF: Acid Detergent Fiber.

Carnauba wax palm fruit procurement and processing

The carnauba wax palm fruit was harvested prior to maturation when the clusters were predominantly colored green. The crop was harvested from April to May in Aracati, Ceará. The fruit was then transported to the experimental farm, dried outdoors, and rotated several times daily to ensure even dehydration. Thereafter, the fruit was milled and stored in polyethylene bags until use.

All procedures were approved by the State University of Ceará Ethics Committee for the experimental use of animals (protocol number 12780187-1).

\section{Body condition score and sternal ultrasound}

The goats were weighed and the body condition score determined weekly as described by MorandFehrandHervieu(1999), until estrussynchronization. During this period, sternal ultrasonography was performed as described by Teixeira et al. (2008) with adaptations. Briefly, the transducer was placed perpendicular to the sternum at the third sternebrae to measure sternal subcutaneous fat. A linear $5 \mathrm{MHz}$ transducer and ultrasound unit was used (Mindray DP 2200 VET, Shenzhen, China). The images were captured in triplicate and each one measured using a calibrated Image ${ }^{\circledR}$ system (Image J, National Institutes of Health, Millersville, USA).

\section{Estrus synchronization and natural breeding}

Estrus synchronization was performed on all does 90 days postpartum using a controlled intravaginal drug release $($ CIDR $\AA)$ device containing 0.33 g progesterone (Eazi-Breed CIDR $\AA$, InterAg, Hamilton, New Zealand) placed in the cranial vagina for 5 days. After the devices were removed, $1 \mathrm{~mL}$ of prostaglandin $\mathrm{F} 2 \alpha$ (Lutalyse ${ }^{\circledR}$, Pharmacia and Upjohn, Kalamazoo, USA) was administered to each doe, and $24 \mathrm{~h}$ later, the does were exposed to two bucks of proven fertility for 72 consecutive hours; each buck was equipped with a marker pigtail, which was situated over the sternum to mark 
the female's rump during any breeding attempt (SILVA et al., 2011). Females were evaluated daily during their exposure to the bucks for the presence of ink on the rump. On evaluation, marked females were considered as having been mounted and were removed from the stall until the end of the 72 hours.

\section{Blood collection}

Blood was collected weekly from the 3rd week postpartum until estrus synchronization. Five blood collections were also performed on days 4, 8, 12, 16 , and 20 after CIDR removal. Blood was obtained from the jugular vein into heparinized tubes (BD Vacutainer ${ }^{\circledR}$, São Paulo Brazil) and centrifuged at $3000 \mathrm{rpm}$ for $15 \mathrm{~min}$. After centrifugation, plasma was recovered and stored until analysis. Progesterone concentration was measured using a commercial kit (Immulite ${ }^{\circledR} 2000$ Progesterone, Siemens Healthcare Diagnósticos LTDA, Llanberis, United Kingdom) and a specific device (Immulite ${ }^{\circledR}$ 2000, Siemens Healthcare Diagnósticos LTDA, Llanberis, United Kingdom).

The sensitivity of the assay kit was $0.1 \mathrm{ng} \mathrm{mL}^{-1}$, and the intra- and interassay variation coefficients were $9.71 \%$ and $12.21 \%$, respectively.

\section{Postpartum luteal activity}

The luteal activity was monitored by measuring plasma progesterone concentrations indicating the presence of corpora lutea. The corpus luteum (CL) was considered functional when progesterone concentrations was greater than $1 \mathrm{ng} \mathrm{mL}^{-1}$ at least two successive samplings; was deemed not functional when progesterone concentrations was greater than 1 ng $\mathrm{mL}^{-1}$ in less than two consecutive samplings; and deemed absent when progesterone concentrations was less than $1 \mathrm{ng} \mathrm{mL}^{-1}$ (RODRIGUES et al., 2011).

\section{Pregnancy diagnosis and fetal development}

Pregnancy was diagnosed ultrasonographically (Mindray DP 2200 VET®, Shenzhen, China) using a $5 \mathrm{MHz}$ linear array transducer on the 30th and 45 th days of pregnancy; the embryonic and fetal structures, vesicle diameter, and crown-rump length were also evaluated at these times as described by Santos et al. (2004). On day 45 of pregnancy, the biparietal, abdominal, and thoracic diameters were measured according to Lee et al. (2005). To measure targeted structures, ultrasonographic examinations were recorded as videos, and at least three images of each structure were subsequently captured and measured using the Image $\mathrm{J} \AA$ program (Image $\mathrm{J} \AA$, National Institutes of Health, Millersville, USA), which was previously calibrated. In a twin pregnancy, the mean of the two embryos or fetuses was analyzed following the method described by Bulnes et al. (1998). The daily embryonic or fetal growth rates (mm/day) were calculated based on these measurements. As described by Silva et al. (2011), when a goat was diagnosed as negative for pregnancy by ultrasound and the progesterone level at 20 days post-CIDR removal was less than $2 \mathrm{ng}$ $\mathrm{mL}^{-1}$, the pregnancy was classified as a pregnancy failure (0-20 days). When does were diagnosed as negative for pregnancy by ultrasound and the progesterone level at 21 days post-CIDR removal

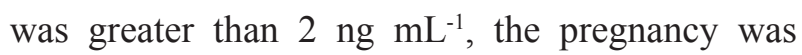
classified as early mortality (21-45 days).

\section{Statistical analysis}

All data were analyzed utilizing the statistical program Statistica ${ }^{\circledR}$ (StatSoft Inc., Tulsa, OK, USA). The body weight, body condition, and litter size were analyzed using PROC GLM. The model for analysis of variance (ANOVA) was performed based on the diet (WCWP, CWP), parturition type (simple or multiple), and factor interactions. The litter size data was transformed into $\log 10$ values. Descriptive ultrasonographic data (sternal subcutaneous fat thickness and ultrasonography fetometry) were analyzed using the GLM procedures for repeated measures analysis of variance (ANOVA). The factors used in the fetometry model 
included diet, parturition type, and interaction, and for the sternal subcutaneous fat thickness were diet, parturition type, time interval, and interactions (diet vs. parturition type and diet vs. time). The recorded anatomic image $(1,2,3)$ was the repeated measure. Means were compared using the $t$ student test. The number of marked goats, pregnancy rate, twinning rate, kidding rate, mortality, $\mathrm{CL}$ analysis, group effect, and parturition type were analyzed by the Kruskal-Wallis ANOVA test. Comparison between numbers was performed using the chi-squared test.

\section{Results and Discussion}

In this study, dry matter intake and orts during the experimental period were significantly influenced by the diet (Table 3). Intake decreased in does consuming carnauba wax palm fruit, which was unexpected result, because feed rejection or clinical signs of intoxication were not observed during the trial or during previous studies. Alves and Coelho (2006) reported that fresh carnauba wax palm fruit is coveted by animals during the dry season, which is when the mature fruit falls to the ground; this pattern was confirmed by producers providing the fruit in this study.

However, several mechanisms maybe responsible for the decreased feed consumption in does offered a carnauba fruit-based diet. To avoid changing the fruit nutrient composition by soil or parasite contamination, the fruit was harvested directly from the plant and therefore, was not mature. Moreover, the fruit milled whole with seed and pericarp parts and dried to generate a usably concentrate, which may decrease the product palatability.
As summarized in Table 2, the carnauba fruitbased concentrate had a higher fiber in acid and neutral detergent content compared to the corn-based concentrate. High fiber content can decreased digestibility and diet consumption, altering the rumen transit rate and reducing nutrient bioavailability.

The body condition score at parturition and prior to estrus synchronization were similar between the two groups (Table 3). However, with the significantly reduced in dry matter intake in the CWP group, the BCS did not completely recover until beginning estrus synchronization $(2.2 \pm 0.15$ vs. $2.0 \pm 0.11$ ). Simultaneously, the subcutaneous sternal adipose tissue (SSCFT) decreased more quickly in the CWP group compared to the WCWP group $(\mathrm{P}<0.01$, Table 3$)$. The adipose tissue measured ultrasonographically is correlated with total body fat reserves (ALAPATI et al., 2010), and the sternal region is the most reliable location for evaluation in goats (TEIXEIRA et al., 2008).

The trend in SSCFT during the experiment, illustrated in Figure 1, reflects the negative energy balance, indicated by decreased ability of the CWP does to recover body fat reserves lost during the early postpartum period. Does in the WCWP group began recovering fat reserves 49 days postpartum, 21 days before the CWP group. As a result, the mean SSCFT at estrus synchronization was significantly higher in the WCWP group than the CWP group $(13.69 \pm 0.57$ $\mathrm{mm}$ vs. $11.93 \pm 0.45 \mathrm{~mm}$, respectively, $\mathrm{P}<0.05)$. 
Table 3. Dry matter intake, orts, body weight, body condition and sternal sub-cutaneous fat thickness (SSCFT), of does fed or not with the fruit of carnauba in the postpartum period. Values are expressed as mean \pm standard error of the mean.

\begin{tabular}{|c|c|c|c|c|c|}
\hline \multirow{2}{*}{ Attributes } & \multicolumn{2}{|c|}{ Diet } & \multicolumn{3}{|c|}{$\mathrm{P}$-value } \\
\hline & WCWP & CWP & Diet & $\mathrm{TP}$ & $\mathrm{D} \times \mathrm{TP}$ \\
\hline $\mathrm{N}^{\mathrm{o}}$ of does exposed & 15 & 13 & & & \\
\hline Dry matter intake, $\mathrm{g} \mathrm{d}^{-1}$ & $739.29 \pm 3.24$ & $646.48 \pm 11.03$ & 0.01 & - & - \\
\hline Orts, $\%$ & $3.14 \pm 0.25$ & $13.97 \pm 1.76$ & 0.01 & - & - \\
\hline Parturition body weight, $\mathrm{kg}$ & $39.84 \pm 2.17$ & $36.73 \pm 1.98$ & 0.36 & 0.35 & 0.75 \\
\hline Parturition body condition & $2.0 \pm 0.11$ & $2.2 \pm 0.15$ & 0.45 & 0.63 & 0.99 \\
\hline $\begin{array}{l}\text { Body condition before estrus } \\
\text { synchronization }\end{array}$ & $2.1 \pm 0.11$ & $2.0 \pm 0.11$ & 0.48 & 0.15 & 0.25 \\
\hline SSCFT at parturition, mm & $13.89 \pm 0.59$ & $13.29 \pm 0.60$ & 0.75 & 0.82 & 0.19 \\
\hline SSCFT loss rate*, $\mathrm{mm} \mathrm{dia}^{-1}$ & $0.03 \pm 0.01$ & $0.05 \pm 0.02$ & 0.01 & 0.52 & 0.61 \\
\hline
\end{tabular}

$\mathrm{D}=$ diet; $\mathrm{TP}=$ type of parturition; $*$ Difference between the measurements made at the time of estrus synchronization and parturition.

Figure 1. Sternal sub-cutaneous fat thickness (SSCFT), during the post-partum period in goat fed with dried carnauba wax palm fruit.

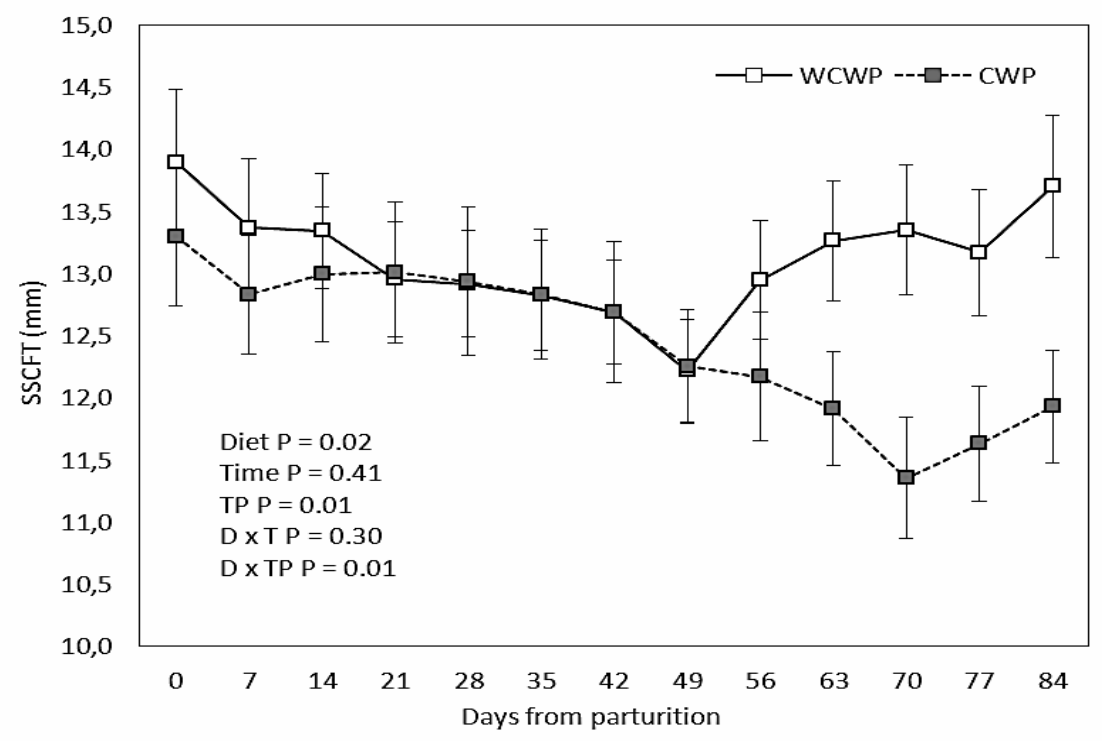

In goats, as in other ruminants, the energy deficit intensity and duration postpartum is greatly impacted by the body condition at parturition and the dry matter consumption rate postpartum (SARTORI; MOLLO, 2007). Under conditions of food restriction or poor body condition, the nutritional requirements are not met, and the body uses stored energy sources such as glycogen, protein, and especially triglycerides, exaggerating the decrease in body reserves. These metabolic changes impact the anovulatory duration and delay the return of ovarian cyclicity (MALAUADULI et al., 2005; SANTIAGO-MIRAMONTES et al., 2009).

Contrary to expectations, the decreased dry matter intake in the CWP group did not affect postpartum luteal activity or the duration to the first functional CL, which lasted a mean days postpartum (Table 4). However, the data did show that functional CL appearance was subject to body condition recovery. In the CWP group, the functional CL arose 70 
days postpartum simultaneously with the fat mass occurred more frequently than a functional or nonrecovery (Figure 1). In both groups, an absent $\mathrm{CL}$ functional $\mathrm{CL}(\mathrm{P}<0.05)$.

Table 4. Time from parturition and first functional corpus luteum (CL), number of goats with functional CL, notfunctional or absence of $\mathrm{CL}$, in does fed or not with the fruit of carnauba in the postpartum period.

\begin{tabular}{|c|c|c|c|c|c|}
\hline \multirow{2}{*}{ Attributes } & \multicolumn{2}{|c|}{ Diet } & \multicolumn{3}{|c|}{$\mathrm{P}$ - value } \\
\hline & WCWP & CWP & Diet & TP & $\mathrm{D} \times \mathrm{TP}$ \\
\hline $\mathrm{N}^{\mathrm{o}}$ of does exposed & 15 & 13 & & & \\
\hline $\begin{array}{l}\text { Interval between parturition and first functional corpus } \\
\text { luteum, days }\end{array}$ & 63 & 70 & 0.99 & 0.18 & 0.22 \\
\hline \multicolumn{6}{|l|}{ Corpus luteum (CL), $\mathrm{n}$} \\
\hline CL functional & $3 a$ & $3 a$ & 0.83 & 0.19 & - \\
\hline CL nonfunctional & 1a & $2 \mathrm{a}$ & 0.46 & 0.24 & - \\
\hline CL absent & $11 \mathrm{~b}$ & $10 \mathrm{~b}$ & 0.82 & 0.17 & - \\
\hline
\end{tabular}

a,b $\mathrm{p}<0.05$ comparison in the same column.

$\mathrm{D}=$ diet; $\mathrm{TP}=$ type of parturition.

Recovered ovarian activity postpartum corresponds to the end of postpartum anestrus and is influenced by numerous factors including, breed, parity, feeding, body condition score at parturition, milk yield, and weaning type (FREITAS et al., 2004; MAIA; COSTA, 1998; ANDRIOLI et al., 1992). Freitas et al. (2004) reported that in the semi-arid Northeast, the postpartum anestrus was 78 and 95 days in Anglo-Nubian and Saanen goats, respectively, when the kid was separated soon after parturition. Takayama et al. (2010) observed an anestrus period lasting 49-70 days postpartum in Shiba goats maintained with their kids, which is similar to the present findings.

Both groups showed a high response to estrus synchronization, with $96.4 \%$ of does marked (Table $5)$. The adopted estrus synchronization protocol is highly effective in goats (OLIVEIRA et al., 2001). Silva et al. (2011), in a study of goats in varying body conditions at calving, and Ciccioli et al. (2003), in a postpartum beef cattle study, both reported high treatment efficacy, regardless of the body condition. According to Rhodes et al. (2003), exogenous progesterone administered during anestrus sensitizes the hypothalamic-pituitaryovarian axis directly or indirectly, and promotes gonadotropin release, stimulating estrus induction.

Despite the high responsive to estrus synchronization, the pregnancy rate was markedly reduced $(\mathrm{P}<0.05)$ in the CWP group, and less than $50 \%$ of does (6/13) were pregnant on ultrasound assessment. The plasma progesterone concentration after mating indicated that pregnancy losses comprised similar frequencies of pregnancy failures (mating to day 20 post-CIDR removal) and early mortality (day 21 post-CIDR removal until pregnancy diagnosis) (Table 5). In both groups, no further losses were recorded through parturition, and therefore, the calving and pregnancy rates are equal. 
Table 5. Reproductive response and fetal measurements of does fed or not with the fruit of carnauba in the postpartum period. Values are expressed as mean \pm standard error of the mean.

\begin{tabular}{|c|c|c|c|c|c|}
\hline \multirow{2}{*}{ Attributes } & \multicolumn{2}{|c|}{ Diet } & \multicolumn{3}{|c|}{$\mathrm{P}$ - value } \\
\hline & WCWP & CWP & Diet & TP & $\mathrm{D} \times \mathrm{TP}$ \\
\hline $\mathrm{N}^{\circ}$ of does exposed & 15 & 13 & & & \\
\hline Does marked, $\%(n / n)$ & $100(15 / 15)$ & $92.31(12 / 13)$ & 0.28 & 0.45 & - \\
\hline Pregnancy rate, $\%(n / n)$ & $86.67(13 / 15)$ & $46.15(6 / 13)$ & 0.02 & 0.51 & - \\
\hline Pregnancy failure, $\%(\mathrm{n} / \mathrm{n}){ }^{*}$ & $50.00(1 / 2)$ & $57.14(4 / 7)$ & 0.10 & 0.82 & - \\
\hline Early mortality, \% (n) ${ }^{* *}$ & $50.00(1 / 2)$ & $42.86(3 / 7)$ & 0.22 & 0.52 & - \\
\hline \multicolumn{6}{|l|}{ Ultrasonographic fetometry } \\
\hline \multicolumn{6}{|l|}{ Diameter of embryonic vesicle, $\mathrm{mm}$} \\
\hline 30 days of gestation & $25.59 \pm 0.42 \mathrm{a}$ & $24.49 \pm 0.87 \mathrm{a}$ & 0.02 & 0.31 & 0.01 \\
\hline 45 days of gestation & $51.20 \pm 0.35 b$ & $51.12 \pm 0.51 b$ & 0.12 & 0.03 & 0.04 \\
\hline Growth rate, $\mathrm{mm}_{\mathrm{dia}} \mathrm{I}^{-1}$ & $1.71 \pm 0.03$ & $1.47 \pm 0.13$ & 0.41 & 0.74 & 0.94 \\
\hline \multicolumn{6}{|l|}{ Crown-rump length, mm } \\
\hline 30 days of gestation & $12.30 \pm 0.22 \mathrm{a}$ & $12.16 \pm 0.34 \mathrm{a}$ & 0.34 & 0.91 & 0.04 \\
\hline 45 days of gestation & $37.03 \pm 0.30 b$ & $39.68 \pm 1.00 b$ & 0.42 & 0.01 & 0.09 \\
\hline Growth rate, $\mathrm{mm}_{\mathrm{dia}}^{-1}$ & $1.65 \pm 0.02$ & $1.56 \pm 0.13$ & 0.67 & 0.55 & 0.93 \\
\hline Biparietal diameter 45 days, $\mathrm{mm}$ & $10.80 \pm 0.11$ & $10.86 \pm 0.18$ & 0.22 & 0.05 & 0.26 \\
\hline Diameter of thorax 45 days, $\mathrm{mm}$ & $8.66 \pm 0.11$ & $8.16 \pm 0.11$ & 0.07 & 0.97 & 0.65 \\
\hline Diameter of abdomen 45 days, $\mathrm{mm}$ & $11.88 \pm 0.11$ & $11.89 \pm 0.18$ & 0.92 & 0.80 & 0.90 \\
\hline Kidding rate, $\%(\mathrm{n} / \mathrm{n})$ & $86.67(13 / 15)$ & $46.15(6 / 13)$ & 0.02 & 0.51 & - \\
\hline $\mathrm{N}^{\mathrm{o}}$ of kids & 18 & 7 & & & \\
\hline Litter size & $1.40 \pm 0.16$ & $1.38 \pm 0.14$ & 0.94 & - & - \\
\hline Twinning rate, $\%(n / n)$ & $38.46(5 / 13)$ & $16.67(1 / 6)$ & 0.35 & - & - \\
\hline
\end{tabular}

$\mathrm{a}, \mathrm{b} \mathrm{p}<0.05$ comparison in the same column, A, B comparison between column . * Pregnancy failure from mating to days 20 after CIDR removal. ** Mortality from days 21 after CIDR removal to pregnancy diagnosis. $\mathrm{D}=$ diet; $\mathrm{TP}=$ type of parturition.

The establishment and maintenance of pregnancy requires the integration of endocrine and paracrine signals from the ovary, conceptus, and uterus (SPENCER; BAZER, 2002); as a result, early pregnancy loss (0-20 days) can occur due to several causes such as ovulation, fertilization, or maternal recognition failures. These losses may reflect low circulating progesterone concentrations immediately before mating and during the early luteal phase in the following cycle, creating a uterine environment inadequate for embryonic development and causing failed maternal pregnancy recognition (MANN; LAMMING, 2001). This maternal recognition of pregnancy occurs due to the synthesis and secretion of IFN $\tau$, performed by mononuclear cells in the conceptus trophectoderm, between days 10 and 25 (ROBERTS et al., 1999; BAZER, 1992). IFN $\tau$ appears to be the sole factor produced by the conceptus that prevents the development of endometrial luteolytic mechanism (BAZER, 1992), primarily through the production of progesterone and estrogens that may directly affect basal PGF2 secretion by the endometrium (ASSELIN et al., 1996; XIAO et al., 1998). According to Bolet (1986), the embryonic mortality rate in sheep and goats is approximately 30\% and occurs primarily during the first month, particularly before implantation; this may be associated with oocyte and embryo abnormalities.

Decreased postpartum fertility in animals in a negative energy balance has been associated with reduced IGF-I and leptin concentrations (MEIKLE et al., 2004), which are directly affected by energy reserve availability during negative energy balance. Silva et al. (2011) reported a markedly decreased pregnancy rate in mixed-breed goats with low 
body condition that had been subjected to estrus synchronization in postpartum, consistent with the present findings for the CWP group, which presented less sternal subcutaneous fat compared to the WCWP group; together, these results show that it is important to evaluate the body condition in breeding goats.

In pregnant animals, ultrasonographic fetometry showed no diet-associated effects, except that the embryonic vesicle diameter was greater in the WCWP group than in the CWP group at 30 days of gestation $(\mathrm{P}<0.05$, Table 5). Despite this result, the embryonic and fetal development outcomes in both groups were within normal ranges for goats (SANTOS et al., 2004). Amer (2010, 2008) used ultrasound to measure crown-rump lengths and biparietal diameters in pregnant goats and found similar values at 45 days of pregnancy. Oliveira et al. (2014), on evaluating the embryonic and fetal development in Canindé goats, found values similar to our study in terms of the diameter of the embryonic vesicle and the crown-rump length for the same period of gestation. At parturition, fecundity was statistically similar $(\mathrm{P}>0.05)$ between the groups, with an overall mean of 1.39 \pm 0.11 kids, and there were no differences in the multiple birth rate between groups. Our findings were similar to those of Sarmento et al. (2010), who reported mean of 1.35 and $35.5 \%$ for litter size and multiple birth rate, respectively, in crossbred Alpine $\times$ Gurguéia reared in a semi-extensive system. Silva et al. (2011) studied Anglonubian $\times$ SPRD goats in the same geographic area of the present experiment, and recorded values of 1.43 and $25 \%$ for litter size and twinning rate, respectively, which were very similar to the findings of our study.

\section{Conclusions}

The substitution of corn with dehydrated carnauba wax palm fruit in concentrated feed for postpartum goats showed no positive effects. Reduced feed intake in the does consuming the carnauba diet caused decreased body reserves, which probably resulted in a decreased pregnancy rate in the affected does. However, given the importance of carnauba wax palm in the semi-arid Northeast, additional studies are needed that investigate varying carnauba supplementation levels to determine its feasibility in productive and reproductive goat management.

\section{Acknowledgments}

Financing institution: Edital MCT-INSA/CNPq $\mathrm{N}^{\mathrm{o}} 35 / 2010$, ref. $\mathrm{n}^{\mathrm{o}}$. 562559/2010-8. The authors thank the technical team of Campo da Semente Farm for their support and help in handling the animals.

\section{References}

ALAPATI, A.; KAPA, S. R.; JEEPALYAM, S.; RANGAPPA, S. M. P.; YEMIREDDY, K. R. Development of the body condition score system in Murrah buffaloes: validation through ultrasonic assessment of body fat reserves. Journal of Veterinary Science, Seoul, v. 11, n. 1, p. 1-8, 2010.

ALVES, M. O.; COELHO, J. D. Tecnologia e relações sociais de produção no extrativismo da carnaúba no Nordeste brasileiro. In: CONGRESSO DA SOCIEDADE BRASILEIRA DE ECONOMIA E SOCIOLOGIA RURAL, QUESTÕES AGRÁRIAS, EDUCAÇÃO NO CAMPO E DESENVOLVIMENTO, 44., 2006, Fortaleza. Anais... Fortaleza: SOBER; UFC; UNIFOR; Banco do Nordeste; Embrapa Agroindústria Tropical, 2006. p. 9.

AMER, H. A. Determination of first pregnancy and foetal measurements in Egyptian Baladi goats (Capra hircus). Veterinaria Italiana, Teramo, v. 44, n. 2, p. 429437, 2008.

AMER, H. A. Ultrasonographic assessment of early pregnancy diagnosis, fetometry and sex determination in goats. Animal Reproduction Science, Manchester, v. 117, n. 3-4, p. 226-231, 2010.

ANDRADE, G. A. P.; BARBOSA, R. R.; BATISTA, J. S.; E SOTO-BLANCO, B. Intoxicação pelas folhas de carnaúba, Copernicia prunifera (Arecaceae), em ruminantes. Ciência Animal Brasileira, Goiânia, v. 9, n. 2, p. 396-401, 2008.

ANDRIOLI, A.; SIMPLICIO, A. A.; MACHADO, R. Influência da época da parição no comportamento reprodutivo pós-parto de cabras Sem Raça Definida. Pesquisa Agropecuária Brasileira, Brasília, v. 27, n. 1, p. 65-72, 1992. 
ARAÚJO FILHO, J. A.; REIS LEITE, E.; LIMA DA SILVA, N. Contribution of woody species to the diet composition of goat and sheep in Caatinga vegetation. Pasturas tropicales, Colombia, v. 20, n. 2, p. 41-45, 1998.

ARRUDA, I. J.; SILVA, L. M.; OLIVEIRA, C. H. A.; SILVA, A. M.; RODRIGUES, F. V.; FERNANDES, C. C. L.; SILVA, C. M. G.; GOMES FILHO, M. A.; ARAÚJO, A. A.; RONDINA, D. Produção de embriões in vivo e expressão dos genes IGF-IR, IGFII, GLUT-I e HSP 70. 1 em embriões de cabras alimentadas com bagaço de caju desidratado ou raspa de mandioca. Revista Brasileira de Ciência Veterinária, Rio de Janeiro, v. 20, n. 1, p. 54-58, 2013.

ASSELIN, E.; GOFF, A. K.; BERGERON, H.; FORTIER, M. A. Influence of sex steroids on the production of prostaglandin F2 and E2 and response to oxytocin in cultured epithelial and stromal cells of the bovine endometrium. Biological Reproduction, New York, v. 54, n. 2, p. 371-379, 1996.

AYRES, M. C. C.; BRANDÃO, M. S.; VIEIRAJÚNIOR, G. M.; MENOR, J. C. A. S.; SILVA, H. B.; SOARES, M. J. S.; CHAVES, M. H. Atividade antibacteriana de plantas úteis e constituintes químicos da raiz de Copernicia prunifera. Brazilian Journal of Pharmacognosy, Curitiba, v. 18, n. 1, p. 90-97, 2008.

BAZER, F. W. Mediators of maternal recognition of pregnancy in mammals. Proceedings of the Society for Experimental Biology and Medicine, Baltimore, v. 199, n. 4, p. 373-384, 1992.

BOLET G. Timing and extent of embryonic mortality in pigs, sheep and goats: genetic variability. In: SREENAN, J. M.; DISKIN, M. G. (Ed.). Embryonic mortality in farm animals. Dordrecht: Martinus Nijhoff Publishers, 1986. p. 12-43.

BULNES, A. G.; MORENO, J. S.; SEBASTIAN, A. L. Estimation of fetal development in Manchega dairy ewes by transrectal ultrasonographic measurements. Small Ruminant Research, Amsterdam, v. 27, n. 3, p. 243-250, 1998.

CHELIKANI, P. K.; AMBROSEB, J. D.; KENNELLYA, J. J. Effect of dietary energy and protein density on body composition, attainment of puberty, and ovarian follicular dynamics in dairy heifers. Theriogenology, New York, v. 60, n. 1, p. 707-725, 2003.

CICCIOLI, N. H.; WETTEMANN, R. P.; SPICER, L. J.; LENTS, C. A.; WHITE, F. J.; KEISLER; D. H. Influence of body condition at calving and postpartum nutrition on endocrine function and reproductive performance of primiparous beef cows. Journal of Animal Science, Champaign, v. 81, n. 12, p. 3107-3120, 2003.
FREITAS, V. J. F.; RONDINA, D.; NOGUEIRA, D. M.; SIMPLICIO, A. A. Post-partum anoestrus in Anglo-Nubian and Saanen goats raised in semi-arid of North-eastern of Brazil. Livestock Production Science, Champaign, v. 90, n. 2-3, p. 219-226, 2004.

GOMES, J. A. F.; LEITE, E. R.; CAVALCANTE, A. C. R.; BOMFIM, M. A. D.; LOBO, R. N. B.; CÂNDIDO, M. J. D.; ROGÉRIO, M. C. P. Qualidade da carcaça de ovinos terminados em confinamento com níveis de bagana de carnaúba na dieta. Revista Brasileira de Saúde e Produção Animal, Salvador, v. 11, n. 2, p. 414-425, 2010.

GOMES, J. A. F.; LEITE, E. R.; CAVALCANTE, A. C. R.; CÂNDIDO, M. J. D.; LEMPP, B.; BOMFIM, M. A. D.; ROGÉRIO, M. C. P. Resíduo agroindustrial da carnaúba como fonte de volumoso para a terminação de ovinos. Pesquisa Agropecuária Brasileira, Brasília, v. 44, n. 1, p. 58-67, 2009.

LEE, Y.; LEE, O.; CHO, J.; SHIN, H.; CHOI, Y.; SHIM, Y.; CHOI, W.; SHIN, H.; LEE, D.; LEE, G.; SUIN, S. Ultrasonic measurement of fetal parameters for estimation of gestacional age in Korean Black Goats. Journal of Veterinary Medicine Science, Tokyo, v. 67, n. 5, p. 497-502, 2005.

MAIA, M.; COSTA, A. N. Estro e atividade ovulatória pós-parto em cabras Canindé associados ao manejo da amamentação. Revista Brasileira de Reprodução Animal, Belo Horizonte, v. 22, n. 1, p. 35-43, 1998.

MALAU-ADULI, B. S.; EDUVIE, L. O.; LAKPINI, C. A. M.; MALAU-ADULI, A. E. O. Influence of crop residue ration supplementation on the attainment of puberty and postpartum reproductive activities of Red Sokoto goats. Journal of Animal Physiology and Animal Nutrition, Berlin, v. 89, n. 1-2, p. 11-19, 2005.

MANN, G. E.; LAMMING, G. E. Relationship between maternal endocrine environment, early embryo development and inhibition of the luteolytic mechanism in cows. Reproduction, Cambridge, v. 121, n. 1, p. 175180, 2001.

MEIKLE, A.; KULCSAR, M.; CHILLIARD, Y.; FEBEL, H.; DELAVAUD, C.; CAVESTANY, D.; CHILIBROSTE, P. Effects of parity and body condition at parturition on endocrine and reproductive parameters of the cow. Reproduction, Cambridge, v. 127, n. 6, p. 727-737, 2004.

MEZA-HERRERA, C. A.; SÁNCHEZ S.; J. M.; CHÁVEZ-PERCHES, J. G.; SALINAS, H.; MELLADO, M. Protein supplementation, body conditionand ovarian activity in goats - pre-ovulatory serum profile of insulin. South African Journal of Animal Science, Champaign, v. 34, p. 223-226, 2004. Supplement 1. 
MORAND-FEHR, P.; HERVIEU, J. Apprécier l'éat corporel des chèvres: Intérêt et méthod. Reussir La Chevre, Versailles, v. 231, n. 231, p. 22-34, 1999.

NATIONAL RESEARCH COUNCIL - NRC. Nutrient requirements of small ruminants. Washington, DC: National Academy Press, 2007. 362 p.

NOGUEIRA, D. H.; LIMA, J. R.; ALVES, R. E. Produção de geléia à base de frutos de carnaubeira. Fortaleza: EMBRAPA, 2009. 4 p. (Comunicado técnico, 143).

OLIVEIRA, C. R. G. S.; MELO, C. H. S.; SOUZAFABJAN, J. M. G.; TELES FILHO, A. C. A.; BATISTA, R. I. T. P.; PEREIRA, A. F.; MELO, L. M.; FREITAS, V. J. F.; TEIXEIRA, D. I. A. Ultrasonographic evaluation of hG-CSF transgenic goat conceptus. Revista Brasileira de Ciências Veterinárias, Rio de Janeiro, v. 21, n. 1, p. 53-59, 2014.

OLIVEIRA, M. A. L.; GUIDO, S. I.; LIMA, P. F. Comparison of different protocols used to induced and synchronize estrus cycle of Saanen goats. Small Ruminant Research, Amsterdam, v. 40, n. 2, p. 149-153, 2001.

OLIVEIRA, S. T.; FARIAS, V. A.; MATA, M. F.; ANDRADE, L. B. S.; JULIÃO, M. S. S. Atividade peroxidásica do extrato protéico do pericarpo de Copernicia prunifera (Mill.) H. E. Moore e Coccthrinax argentata (Jacq.) L. H. Baily. In: REUNIÃO ANUAL DA SOCIEDADE BRASILEIRA DE QUÍMICA, 34., Florianópolis, 2011. Anais... Florianópolis: [s.n.], v. 1.

PARENT, R. A.; COX, G. E.; BABISH, J. G.; GALLO, M. A.; HESS, F. G.; BECCI, P. J. Subchronic feeding study of carnauba wax in Beagle dogs. Food and Chemical Toxicology, England, v. 21, n. 1, p. 85-87, 1983 a.

PARENT, R. A.; RE, T. A.; BABISH, J. G.; COX, G. E.; VOSS, K. A.; BECCI, P. J. Reproduction and subchronic feeding study of carnauba wax in rats. Food and Chemical Toxicology, England, v. 21, n. 1, p. 89-93, 1983 b.

PATE, F. M.; ALVAREZ, J.; PHILLIPS, J. D.; EILAND, B. R. Sugar cane as a cattle feed: production and utilization. Florida: Department of Animal Sciences, Institute of Food and Agricultural Sciences, University of Florida, 2002. 21 p. (Bulletin n. 844).

PEREIRA, E. M. O. Torta de cupuaçú (Theobroma grandiflorum) na alimentação de ovinos. 2009. Tese (Doutorado em Zootecnia) - Universidade Estadual Paulista, São Paulo.

RHODES, F. M.; MCDOUGALL, V.; BURKE, C. R.; VERKERK, G. A.; MACMILLAN, K. L. Treatment of cows with an extended postpartum anestrous interval. Journal of Dairy Science, Madison, v. 86, n. 6, p. 18761894, 2003.
ROBERTS, R. M.; EALY, A. D.; ALEXENKO, A. P.; HAN, C. S.; EZASHI, T. Trophoblast interferons. Placenta, England, v. 20, n. 4, p. 259-264, 1999.

RODRIGUES, M. R. C.; RONDINA, D.; ARAÚJO, A. A.; SOUZA, A. L.; NUNES-PINHEIRO, D. C.; FERNANDES, A. A. O.; IBIAPINA, F. L. Respostas reprodutivas e metabólicas de ovelhas alimentadas com bagaço de caju desidratado, durante o pós-parto. Arquivo Brasileiro de Medicina Veterinária e Zootecnia, Belo Horizonte, v. 63, n. 1, p. 171-179, 2011.

ROWLAND, I. R.; BUTTERWORTH, K. R.; GAUNT, I. F.; GRASSO, P.; GANGOLLI, S. D. Short-term toxicity study of carnauba wax in rats. Food and Chemical Toxicology, England, v. 20, n. 4, p. 467-471, 1982.

RUFINO, M. S. M.; ALVES, R. E.; BRITO, E. S.; PÉREZ-JIMÉNEZ, J.; SAURACALIXTO, F.; MANCINI-FILHO, J. Bioactive compounds and antioxidant capacities of 18 non-traditional tropical fruits from Brazil. Food Chemistry, England, v. 121, n. 4, p. 996-1002, 2010.

RUFINO, M. S. M.; ALVES, R. E.; BRITO, E. S.; SILVEIRA, M. R. S.; MOURA, C. F. H. Quality for fresh consumption and processing of some non-traditional tropical fruits from Brazil. Fruits, Cambridge, v. 64, n. 5, p. 361-370, 2009.

RUFINO, M. S. M.; ALVES, R. E.; FERNANDES, F. A. N.; BRITO, E. S. Free radical scavenging behavior of ten exotic tropical fruits extracts. Food Research International, Canada, v. 44, n. 7, p. 2072-2075, 2011.

SANTIAGO-MIRAMONTES, M. A.; MALPAUX, B.; DELGADILLO, J. A. Body condition is associated with a shorter breeding season and reduced ovulation rate in subtropical goats. Animal Reproduction Science, Manchester, v. 114, n. 1-3, p. 175-182, 2009.

SANTOS, M. H. B.; OLIVEIRA, M. A. L; LIMA, P. F. Medidas do concepto utilizadas na prática ultrasonográfica de pequenos ruminantes. In: OLIVEIRA, J. F. Diagnóstico da gestação na cabra e na ovelha. São Paulo: Varela Editora e Livraria, 2004. p. 137-157.

SARMENTO, J. L. R.; PIMENTA FILHO, E. C.; ABREU, U. G. P.; RIBEIRO, M. N.; SOUSA, J. E. R. Prolificidade de caprinos mestiços leiteiros no semiárido nordestino. Revista Brasileira de Zootecnia, Viçosa, MG, v. 39, n. 7, p. 1471-1476, 2010.

SARTORI, R.; MOLLO, M. R. Influência da ingestão alimentar na fisiologia reprodutiva da fêmea bovina. Revista Brasileira de Reprodução Animal, Belo Horizonte, v. 31, n. 1, p. 197-204, 2007. 
SILVA, C. G.; HERDEIRO, R. S.; MATHIAS, C. J.; PANEK, A. D.; SILVEIRA, C. S.; RODRIGUES, V. P.; RENNÓ, M. N.; FALCÃO, D. Q.; CERQUEIRA, D. M.; MINTO, A. B. M.; NOGUEIRA, F. L. P.; QUARESMA, C. H.; SILVA, J. F. M.; MENEZES, F. S.; ELEUTHERIO, E. C. A. Evaluation of antioxidant activity of Brazilian plants. Pharmacological Research, London, v. 52, n. 3, p. 229-233, 2005.

SILVA, L. M.; OLIVEIRA, C. H. A.; SILVA, A. M.; SILVA, C. M. G.; CASTRO, S. V.; CARVALHO, A. A.; DUARTE, A. B. G.; COSTA, E. C.; FELTRIN, C.; FIGUEIREDO, J. R.; RONDINA, D. In vitro development of ovine preantral follicles and oocyte cleavage rate are not affected by long-term ingestion of detoxified castor meal. Small Ruminant Research, Amsterdam, v. 113, n. 2-3, p. 353-359, 2013.

SILVA, L. M.; RONDINA, D.; ARAÚJO, A. A.; SARGENTINI, C.; LIMA, I. M. T.; RODRIGUES, M. R. C.; SOUZA, A. L.; GIORGETTI, A.; OLIVEIRA, C. H. A.; RODRIGUES, F. V. Reproductive responses and progesterone levels of post-partum oestrus synchronization in goats with different body reserves. Italian Journal of Animal Science; Champaign, v. 10, n. 4, p. 160-164, 2011.

SPENCER, T. E.; BAZER, F. W. Biology of progesterone action during pregnancy recognition and maintenance of pregnancy. Frontiers in Bioscience, v. 7, n. 1, p. 18791898, 2002.
TAKAYAMA, H.; TANAKA, T.; KAMOMAE, H. Postpartum ovarian activity and uterine involution in non-seasonal Shiba goats, with or without nursing. Short communication. Small Ruminant Research, Amsterdam, v. 88, n. 1, p. 62-66, 2010.

TEIXEIRA, A.; JOY, M.; DELFA, R. In vivo estimation of goat carcass composition and body fat partition by real-time ultrasonography. Journal of Animal Science, Champaign, v. 86, n. 9, p. 2369-2376, 2008.

VELAZQUEZ, M. A. Impact of maternal malnutrition during the periconceptional period on mammalian preimplantation embryo development. Domestic Animal Endocrinology, Auburn, v. 51, n. 1, p. 27-45, 2015.

XIAO, C. W.; LIU, J. M.; SIROIS, J.; GOFF, A. K. Regulation of cyclooxygenase-2 and prostaglandin $\mathrm{F}$ synthase gene expression by steroid hormones and interferon-tau in bovine endometrial cells. Endocrinology, Washington, v. 139, n. 5, p. 2293-2299, 1998.

ZARAZAGA, L. A.; GUZMÁN, J. L.; DOMÍNGUEZ, C.; PÉREZ, M. C.; PRIETO, R. Effect of plane of nutrition on seasonality of reproduction in Spanish Payoya goats. Animal Reproduction Science, Manchester, v. 87, n. 3-4, p. 253-267, 2005. 
